\title{
Türk hukukunda evlenmenin tabiiyete tesiri
}

\author{
Doç. Dr. Osman Fazll Berki
}

\author{
G İ R İ Ş
}

Bir şahsı veya bir şey'i Devlete bağllyan hukukî ve siyasî bağdan ibaret olan tabiiyetin "uyrukluk" hukukî mahiyeti üzerinde ittifak edilmiş değildir. Bazı müelliflere göre tabiiyet meflıumunun esasını, devletle ferd arasında aktedilmiş bulunan mukavelede aramak lâzımdir. (1).

Fakat buguin hemen umumiyetle tabiiyet, bir âmme hukuku münasebeti olarak mülâhaza olunmakta ve mukavele mefhumu drşında kalmaktadır.

Tabiiyetin hukukî mahiyeti hakkındaki bu görüş ayrılığı ehemmiyetsiz addedilmemelidir. Tabiiyeti bir hususî hukuk münasebeti, bir mukavele addedenler, şahsın iradesini nazarı itibara almaksızın devletin, tabiiyet verme ve almada bịr hakka malik olacağını kabul etmemektedirler. Bu noktai nazar, hiç şüphesiz, esası, rızaların birleşmesinden ibaret olan bu hukukî ve siyasî bağın mahiyetine uygun düser.

Tâbiiyeti bir âmme hukuku münasebeti sayanlar, bu sahada, ferdî iradenin ancak devlet tarafından tanınan hallerde rol oynıyabileceğini kabul eylemektedirler.

Her devlet, bir şahsın kendi tabiiyetinde olup olmadığını serbestçe tâyin etmek yetkisine sahiptir. Ve bunu yaparken, hàkimiyet hakkını kullanmaktadır. Devletin bu serbestisi, Devletler Hukukunda itiraza uğramamaktadır.

Genel olarak kabul edildiğine göre, tabiiyet devletin teşekkül ve bekasınin esasını teşkil erer. Bunu tam bir bağımsızlıkla düzenlemek devlet için hayatî bir önemi haizdir. İşte, bu bağımsızlığa istinat ederek devlet, tebaasinı tâyin eder; başka bir deyimle, tabiiyetin iktisabı ve ziyar hakkınđaki prensipleri kendi telâkkilerine, tesiri altında kaldığı fikirlere ve yüksek menfaatlerine göre tesbit eyler.

(1) Weiss, Manuel de droit international prive, 9.e edition p. 2, Cogordan, la nationalité au point de vue des rapports internationaux. p. 7 
I

\section{EVLENME VE TABIIYET}

Devletlerin, evlenme ile tabiiyet iktisap edilip edilmiyeceği hususunda da tam bir serbestî ile hareket edecekleri tabiidir. Evlenmenin, kadının tabiiyetine tesir edip etmiyeceği mes'elesi ihtilâfll-' dir. Bu mes'ele hákkında birbirine zıd iki tez mevcuttur.

Bunlardan birisi, ailede tabiiyet birliği hakkındaki tezdir ki, buna "klasik tez" adi verilmektedir.

Diğeri, kadının tabiiyetinin bağımsızlığı hakkındaki tezdir ki, buna "modern tez" denilmektedir. Bu tezlerden her biri nazarì ve amelî bir takım delillere dayanmaktadır.

KIâsik tez, her şeyden evvel, kocanm otoritesine tâbi olan evli kadının ehliyetsizliğine dair olan fikirden ilham almaktadır. Bu noktai nazara göre, ailede tabiiyet birliği prensibi kocanın hâkimiyeti prensibine istinad etmektedir.

Bu teze iştirâk edenler, ailede tabiiyet birliği mes'elesini, karının ehliyetsizliği fikrinden başka, daha önemli bit delil saydıkları ailenin menfaati esasma da istinat ettirmektedirler.

Klâsik tez taraftarlarına fikrince, modern tezin bir takım mahzurları vardır. Ve bu mahzurlarm mevcudiyeti dolayısiyle kabulü imkânsızdır.

Siyasî ve millî bakımlardan, bilhassa harp zamanında, tebaa ile evlenen yabancı kadınların, yabancı, belki de düşman devlet hâkimiyetine bağlı kalabilmeleri devlet için arzu edilir bir ş̧ey değildir.

Nihayet evlilik birliğinde, tabiiyet ikiliği, aile içinde bir çok ihtilâfların doğumuna sebep olur. Karı koca arasındaki hukukî münasebetleri, evlenmenin hüküm ve neticelerini ve ortadan kalkmasını, velâyet hakkının kullanılmasını hangi kanunun tanzim edeceği mes'elesi çok önemli, ve halli müşkül ihtilâfların ortaya çıkmasina sebep olur.

Klâsik tez taraftarlarının noktai nazarlarını haklı göstermek için ileri sürdükleri bu mâkuI delillere rağmen, mudern tez taraftar bulmaktadır. Bu teze taraftar olanlar, evli kadının ehliyetsizliğine dair olan eski prensibi ylkan genel fikir hareketine dayanmaktadirlar. Bunlara göre, hemen her yerde kadınlar ehliyetsiz olmaktan kurtulmuşlar, ve bugünkü cemiyette erkeklerinkine eşit bir yer almışlardır. Bu böyle olunca, karının tabiiyet bakımından kocasina bir gayri reşid gibi bağlı oIması anlaşılmaz. 
Pozitif hukuk, incelemekte olduğumuz konuda, ileriye doğru adım atmıştır. Feminizm alanında varılan önemli sonuçlar ve bir çok memleketlerde kadının siyasî haklar elde etmiş olması, kadına tabiiyet almak hususunda büyük bir muhtariyet verilmesi neticesini doğurmuştur.

Şunu da derhal kaydedelịm ki, modern tez henüz genel olarak kabul edilmiş olmaktan uzaktır.

Hulâsa: Kanunların tanziminde devletlerin tam bir istiklâle sahip olmaları ve kadının tabiiyeti mes'elesinde feminizm ve nüfusun çoğaltılması gibi düșüncelerin hâkim olması dolayısiyle, muhtelif memleketlerde kabul edilen sistemler birbirine uymamakta ve bundan bir çok arzu edilmiyen neticeler doğmaktadır. Kanumların başka basska prensipleri ihtiva etmesi, bazan kadmın tabiiyetsiz, "Haymatlos) bazan çifte tabiiyetli olmasinı intaceder. Bu gibi mahzurların önüne geçmenin güçlüğü aşikârdır.

\section{II \\ TABİIYETI OSMANIYE KANUNUNDAN EVVELKI HUKUKTA EVLENMENIN TABİYYETE TESIRI}

Islâm memleketlerinde tabiiyet mefhumu zamanımızda olduğu gibı anlaşılmamıştı. Müslüman memleketlerde ahałi üç kısma ayrıliyordu:

1 - Müslümanlar, 2-- Zimmiler, 3-Müstemenler,

Müslümanlar hangi devlete bağlı olurlarsa olsunlar yabancı addedilmezlerdi.

Zimmiler yaşadıkları memleketin tebaasından idiler. Müstemenler darülislâma âman ile giren yabancılardı. (2).

Şer'î hukukta müstemen olan kadın, bir müslïman Osmanlı ile veya Zimmi ile evlenirse Osmanlı tabilyetini aliy»rdu. Yabancı ile evlenen Osmanlı kadını tabiiyetini muhafaza ediyordu.

III

TABİYYYTI OSMANIYE KANUNUNA GÖRE EVLENMENIN TABİYYETE TESIRI

A - Türk tabiiyetinde olan kadının yabancı ile evlenmesi 8/Ocak/1284 tarihli tabiiyeti Osmaniye kanunnamesinin (3) 7 inci

(2) Daha fazla tafsilât için Bak. Muammer Raşid Sevig, Devletler hususî hukuku, s. 171 ve $M$.

(3) Bu kanunname metni için Bak. Birinci tertip düstur. Cilt: 3. Sh. 16. 
maddesi bu mes'eleyi evlenmenin zevali dolayısiyle bahis konusu etmektedir. Bu maddeye göre: "Tebaai devleti âliyeden iken ecnebî ịle tezevvüceden kadın zevcinin vefatı tarihinden itibaren üç sene zarfinda istida ederse tabiiyeti asliyesine ric'at edebilir. Bu maddenin hükmü şahsa şamildir. Tasarrufu emlâk ve arazi maddesi nizamat ve kavanini umumiyeșine tâbidir.).

Bu maddeden anlaşlacağı üzere, Osmanlı tabiiyetinde olan kadin bir yabanci ile evlendiği takdirde aslî tabiiyetini kaybetmekte, yani Osmanlı tabiiyetinden çlkarak kocasınm tabiiyetine geçmektedir.

B - Yabancı bir kadının Türkle evlenmesi — tabiiyeti Osmaniye kanunnamesinin 7 inci maddesi, yalnız ecnebi ile evlenen Osmanls tabiiyetinde bulunan kadınlar hakkında hüküim sevketmekte, Türkle evlenen yabancı kadınlar hakkında hiç bir sarahati ihtiva eylememektedir. Fakat birinci fıkradan istidlâl olunabileceği gibi, Türkle evlenen ecnebî kadınlar hakkında da hüküm aynıdır (4).

Kanunun' yabancı kadınlar hakkındaki sükûtundan istifade eden yabancı memleketler doktrin ve mahkeme içtihadiarı bunun aksini iddia etmişler, Fransız ve İtalyan mahkemeleri Türklerle evlenen tebaalarının Türk tabiiyetini alamıacaklarını karar altına almışlardir. (5). Tabiiyet kanunundaki bu boşluk 18/Cemaziyelevvel/1301. ve $6 / \mathrm{Mart} / 1300$ tarihli "Saltanatı Seniyye şehbenderlerine dair nizamnamei dahilî" nin 59 uncu bendiyle doldurulmuştur. Filhakika, bu bende göre "Tebaai ecnebiyeden olup da Devleti Âliyye tebaasından birini tezevvüceden kadmlar dahi emri tenakûhla Saltanatı Seniyye tabiiyetine dehâlet edecekleri cihetle kaydolunur».

Hulâsa: Türk vatandaşlığı kanunundan evvel mer'í olan hükümler, ecnebilerle evlenen Türk kadınlarının Türk tabiiyetini kaybedeceklerini ve Türklerle evlenen ecnebi kadınlarnn Türk tabiiyetini. alacaklarinı âmirdir.

IV

TÜRK VATANDAŞLIĞI KANUNUNA GÖRE EVLENMENIN TABIIYETE TESIRI

A - Türk tabiiyetinde olan kadının yabancı ile evlenmesi 1/Ocak/1929 da yürürlüğe giren 28/Mayıs/1928 tarih ve 1312 numa-

(4) Tevfik Kâmil, Hukuku düveli hususiye, 1927, Sh. 47.

(5) Daha fazla tafsilât için Bak: Reşad Aksoy, Ia nationalité dè là femme mariée et des enfants mineurs en droił turc, thése Fribourg, P. 48 et ss.

Hukuk Fakültesi Mecmuası 4 
ralı vatandaşlık kanunumuzun 13 üncü maddesinir 2 inci fıkrası şu hükmü ihtiva etmektedir: “Ecnebilerle evlenen Türk kadınları Türk kalırlarn. Bu fukra mucibince Türk tabiiyetinde olan kadınların yabancılarla evlenmeleri, aslî tabiiyetlerinin ziyar için sebep teşkil edemez. Binaenaleyh, bu kanunun mer'iyet iktisabl tarihi olan 1/Ocak/1929 da veya bu tarihten sonra yabanclarla evlenecek olan Türk kadınları kemakân Türk vatandaşı olarak kàırlar. Ancak nüfus sicilleri kayitlarına ve hüviyet cüzdanlarına kimle evlenmişse, onun adı ve tabilyeti ve evlenme vukuatı şerh verilmekle iktifa olunur.

B - Yabancı kadının Türkle evlenmesi - Türk vatandaşlığı kanununun 13 üncü maddesinin biricin fıkrası "Türklerle evlenen ecnebi kadınlar Türk vatandaşı olurlar) denmekle evlenmenin kadınm tabiiyetine tesir edeceğini kabul ediyor ve bu suretle evlenmede tabiiyet birliği prensibine yer veriyor. (6). İşte bı hükme nazaran, Türkle evlenen ecnebi kadm, evlenmekle haiz olduğu aslî tabiiyeti

(6) Devletlerin bugünkü mévzuatları gözden geçirilecek olursa evlenmenin tabiiyete tesiri hakkında kabul olunan sistemler şu şekilde tasnif ve hulâsa olunabilir:

I- Kadin tarafından kocasının tabilyetinin iktisabl.

1 -.. Otomatik iktisabi kabul eden devletler: Afganistan, Almanya, Arnavutluk, Bolivya. Çekoslavakya, Danimarka, Son Dominiko, Finlandiya, Hayti, Hunduras, İngiltere, İran, Irak, İsvę, İsviçre, İtalya, Japonya, Kanada, Kostorika, Lihtenştayn, Macaristan, Mısır, Monako, Nikaragua, Norveç, Peru, Polonya, Portekiz, Siyam, Veneziela, Yunanistan.

2 - İktisabi şartla kabul eden devletler:

a - Kadının bir beyanname imza etmesi şartiyle: ispanya.

b - Kadının kocasınin tabiiyetini reddetmemesi şartiyle: Belçika, Ekvatör, Holanda, Kûba, Rumanya, Yugoslavya.

c - Kadının istidada bulunması şartiyle: Bulgaristan, Filistin, Fransa, Guatamala, Lüksenburg.

$\mathrm{d}$ - Kadının aslî tabiiyetini kaybetmesi şartiyle: Cin.

e -- Kadının, kocasının memleketinde ikameti şartiyle: Meksika, Salvador.

II - İktisabı kabul etmiyen devletler: A. B. D. Arjantin, Brezilya, Kolombiya, Panama, Parguay, Rusya, Şili. Uruguay.

III - Kadının aslî tabiiyetini kaybetmesi:

1 - Otomatik kaybı kabul eden devletler: Afganistan, Almanya, Finlandiłya, Irak, Hayti, Hunduras, Lihtenştayn, Macaristan, Peru.

2 - Kaybi sartla kabul eden devletler:

a - Kadının, kocasının tabiiyetini iktisap etmesi şartiyle kabul eden devletler: Belçika, Danimarka, Felemenk, İtan, İsveç, İsviçre, İtalya, Japonya, Kanada, Kostarika, Lüksenburg, Misıi, Monako, Norveç, 
kaybedecek, yani evlenme akdi burada menfî bir tesir icra eyleyecek ve kocasının tabiiyetini, Türk vatandaşliğını alacak bu suretle evlenme müsbet bir tesir icra etmiş olacaktır. Bu hüküm ile vazı kanunun Türk nüfusunu çoğaltmak siyasetini takibettiği şüphesizdir.

1 - Türk tabiiyetinden sskat edilen kadmlar -

Türk tabiiyetinden iskat edilmiş olan kadınlar Türklerle evlenirlerse vatandaşlık kanununun 13 üncü maddesinin birinci fłkrası hükmünden istifade edecekler mi, yani Türk vatandaşlığı vasfını iktisap eyliyecekler midir?

Vatandaşlık kanunumuzun 14 üncü maddesi gözönünde tutulacak olursa bu soruya menfî cevap vermek icabeder. Filhakika, bu madde şöyle bir hüküm ihtiva etmektedir: "Hükûmetin müsaadei mahsusasiyle yabancı bir devlet tabiiyetine giren Türkler müracaat ettikleri takdirde ikamet şartına tâbi olmaksızın tcra Vekilleri Heyeti karariyle tekrar Türk vatandaşlığın iktisap edebilirler. Müsaade ile ecnebi tabiiyetine girenlerin, vatandaşlıktan sskat edilmiş olanların evlâtları ikamet şartına tâbi olmaksızın Türk vatandaşl1ğını talep ve İcra Vekilleri Heyeti karariyle iktisap edebilirler"

Demek oluyor ki, vatandaşlık kanunu müsaade ile Türk tabiiyetinden çıanlara ve onların evlâtlarına Türk tabiiyetini iktisap için müracaat hakkı tanımakta, sskat edilenlerin yalnız çocuklarına böyle bir salâhiyet vermekte ve iskat edilenlerden bahsetmemekte olmasına göre Türk uyrukluğundan çıkarılmış olar: şahıslarm herhangi bir şekilde Türk vatandaşlığmı alabilmeleri imkân dahilinde değildir. Fikrimizce maddenin bu şekilde tefsiri kanunun ruhuna ve sskatın cezaî mahiyetine uygun düşer. Nitekim bu husus 2/Haziran/1938 tarih ve 3529 numaralı "Ecnebilerin Türkiyede ikamet ve seyahatları hakkından ki kanunun 25 inci maddesiyle de teyit edilmiş bulunmaktadır. Bu madde şöyledir kbu kanun mucebince sınır dışı edilmiş olan veya umumî hükümlere göre Türk vatandaşlı̆̆ını

Nikaragua, Polonya. Portekiz, Romanya, Salvador, Sondominiko, Siyam, Venexiela, Yugoslavya.

$\mathrm{b}$ - Kadının, eslî tabiiyetini reddetmesi veya kocasinın tabiiyetini ihtiyar eylemesi şariyle kabul eden devletler: Bulgaristan, Cin, Fransa, Guatamala tspanya.

c - Kadının aslî tabiiyetini ihtiyar etmemesi şartiyle kabul eden devletler: Rumanya, Yugoslavya.

TV - Kaybı kabul etmiyen devletler: A. B. D. Arjantin, Bolivya, Brezilya, Ekvatör, Filistin, Kolombiya, Kûba, Meksika, Panama, Parguay, Rusya, Uruguay. 
kaybetmiş bulunan ecnebi kadınlarla sumr dişı edilınesine veya vatandaşlıktan sskatina evlenme muamelesinin tekemmülünden evvel karar verilen ecnebi kadınlar 1312 numaralı Türk vatandaşhğg kanununun 13 üncü maddesiyle ecnebi kadınlara bahședilen haktan istifade edemezlerm.

2 - Müsaadei mahsusa ile Türk tabiiyetinden çlkan kadınlar Hükûmetin müsaadei mahsusiyle Türk vatandaşlığından çıkan kadinlar, Türklerle evlenirlerse Türk uyrukluğunu iktisap edecekler midir?

Vatandaşlık kanununun 14 ünë̈ maddesinin birinci fıkrasmın lâfzına istinat edilecek olursa bu soruya müsbet cevap vermek icabeder. Cünkü, bu fıkra mucebince Hükûmetin müsaadei mahsusiyle ecnebî bir devlet tabiiyetine giren Türkler müracaat ettikleri takdirde ikamet şartına tâbi olmaksızın İcra Vekilleri Heyeti karariyle tekrar Türk vatandaşlığın iktisap edebilirler. Vatandaşliktan iskatta böyle bir müracaat hakkı tanınmadığına nazaran, neticenin de ayrı olması gerekir.

Fakat kanun vazı burada, Türk tabiiyetinden müsaade ile çkanların yeniden Türk vatandaşlı̆̆ını alabilmeleri için iradelerini sarih olarak izhar eylemelerini şart kilmaktadur.

Müsaade ile Türk vatandaşlığmndan çlkan kimse, Türk Devletine bağlı kalmayı arzu etmediği içindir ki, haiz olduğu tabiiyeti terketmistir. Niyeti ne olursa olsun, yabancı kadın Türkle evlendiği takdirde otomatik olarak Türk uyrukluğu alacağına göre Türklükle alâkasını kesmiş olana zorla vatandaşlık vermek olur ki, bunda hiç bir fayda melhuz değildir. Diğer taraftan, Türk tabijyetinden müsaade ile cıkan kadının Türk vatandaşlığı vasfını yeniden iktisap etmesi için evlenmesine lüzưm olmadiğı zikri geçen 14 üncü maddeden de anlaşılmaktadır. Ancak bu cümle ile ifade etmek istediğimiz noktai nazara itiraz edilerek denilebilecektir ki, Hükûmet müsaadei mahsusa ile çıkan sabık Türklere Türk vatandaşlığını verip vermemekte muhtardir. İsterse verir, istemezse vermez. Binaenaleyh, bunların 14 üncü madde hükmünden istifade etmeleri mutlak değildir.

tlk bakışta bu itiraz doğru gibi görünür. Fakat, hükûmet bu dưumdá olan şahısları yeniden Türk vatandaşları arasına almak istemiyorsa bunlarm evlenme müessesesinden faydalanarak gayelerine vâsıl olmalar hukukan tecviz olunabilir mi?

Bize göre hayır. Çünkü, bu gibi kimselerin Türk vatandaşhı̆ını almak istemeleri hüsnü niyete makrün sayılamaz. 
Yukarḍa arzettiğimiz mülâhazalarla demek istiyoruz ki, müsaadei mahsusa ile Türk tabiiyetinden çlkmış olan kadınlar Türklerle evlenseler dahi Türk tabiiyetini alamazlax.

Nitekim bu hal sureti, evvelce de bilmünasebe bahsetmis olduğumuz cenebilerin Türkiyede ikamet ve seyahatları hakkındaki kanunun 25 inci maddesiyle teyit edilmiştir. Kanun bu maddesinde «bu kanun mucibince sınır dışl edilmiş olan veya umumî hükümlere göre Türk vatandaşlığıni kaybetmiş bulunan kadınların Türk vatandaşlığ kanununun 13 üncü maddesiyle ecnebi kadinlara bahşedilen haktan istifade edemiyeceklerini” tasrih eylemektedir.

Binaenaleyh, müsaade ile Türk vatandaşhı̆ından çıkmış olan kadmlar Türklerle evlendikleri takdirde, Türk vatandaşlığını tekrar iktisap etmek istiyorlarsa hükûmete müracaat etmek mecburiyetindedirler.

C - Tabiiyete tesiri bakımindan evlenmelerin tetkikn:

. 1 - Muteber evlenmeler - evlenmenin kadinin tabiiyetine tesir edebilmesi, yani yabancı tabiiyetten çıkarak Türk tabiiyetini alabilmesi için sahih olması lâzımdır. Şu halde yabancı kadın hàngi memlekette olursa olsun bir Türk vatandaşiyle muteber addedilecek surette evlenecek olursa (7) evlenme akdinin in'ikadı tarihinden itibaren kocasına izafetle Türk vatandaşhğgni iktisap etmiş olur.

2 - Batul evlenmeler - Evlenme gerek nisbi ve gerek mutlak butlan sebeplerinden birinin meveudiyeti halinde batıl olsa bile, Medeni Kanunumuzun (124) maddesi mucibince butlan kararna kadar sahih bir evlenmenin bütün hüküm ve neticelerini doğurur. Kanunumuzun bu sarih hükmü, evlenmenin bâtıl olmass takdirinde dahi Türkle evlenen yabancı kadinm kocasmm tabiiyetini, Türk vatandaşĭğını almasını icabettirmektedir.

3 - Câlî evienmeler - Câlî evlenmeler öyle evlenmelerdir $\mathbf{k i}$, bununla taraflar, evlenme müessesesi kullanlmaksızın elde edilmesi mümkün olmiyàn bazı amaçlara ulaşmağı temine çalışılar.

Câlî evlenmeler, evlilik bağmm doğurduğu kanunî neticelerden bir çoklamna tarafların riayet etmek istemiyerek, yani bu neticeleri ne arzu ne de kabul ederek aktettikleri evlenmelerdir. (8).

İsviçrede kesretle vukua gelen, mahkemeleri ve müellifleri işgal

(7) Böyle bir evlenmenin muteber olabitmesi için evlenme hakkındaki kanunlar ihtilâfını idare eden esaslara uygun olarak vaki olması lâzmndır.

(8) Albert Rịchard, Câlî evlenmeles (terceme ve not eden Ferit Hakkt Saymen. s. 482. 
etmiş ve etmekte bulunmuş olan câlî evlenmelerin kadına bir pâye veya bir isim veya bir tabiiyet elde etmesini veya bir kanun hükmünden istifade veya idarî mahiyette olan bir tedbirden kurtulmasim temin veya nesebi sahih olmiyan bir çocuğun nesebinin tashihi için aktedildiğine tesadüf olunmaktadir (9).

Câlî evlenmeler yalnxz hukuku ihlâl eden haller değil, aynı zamanda âmme intizamina mugayir fiillerdir ki, bunlara karşı koymak gerekmektedir. Bugün Borçlar Kanununda ve Medenî Kanunda mevcut hükümlerle bu evlenmeleri muteber addetmemek imkânsızdir. Zira, gayesinin veya mevzuunun ahlâka âdaba mugayir olması dolayısiyle bu gibi evlenmeler bâtıl addedilemiyeceği gibi muvazaalı bir muamele de sayılamaz. (10).

Câli evlenmeler mevcut olmiyan bir evlenme mahiyetini arzetmediği gibi bu evlenmeler hakkın sui istimali prensibine dayanlarak da hükümsüz addolunamaz. (11).

Mahiyetini izah etmeğe çalıştığımız câlî evlenmelerin memleketimizde de vuka gelmesi ihtimali vardır. Türk vazı kanunu, ecnebilerin Türkiyede seyahat ve ikametleri hakkındaki kanunun 25 inci maddesiyle bu evlenmelere az çok mâni olmiya çaiışmış bulunmaktadir.

4 - Mevcut olmıyan evlenmeler - Varlığı için lâzım olan esaslı merasime riayet edilmeksizin yapllan evlenmeler "matrinionium non existens" mevcut olmyan evlenmelerdir. Nikôh memuru önünde yapılmamış bir evlenme gibi. Bu evlenmeler hiçbir hukukî hüküm ve netice tevlid edemiyeceklerine göre Türkle evlenen yabanci kadın Türk vatandaşlığını iktisap edemez. (12). Bu itibarla bu kadının Türlkiyede göreceği muamele tamamen yabancı muamelesi olacaktir.

(9) Albert Rịchard, adı geçen eser, s. 482.

(10) Albert Richand, ayni eser, s. 489.

(11) İsviçre Federal Mahkemesi 29/II/1940 tarihinde verdiğg bir kararla hakkın sui istimali prensipine dayanarak câlî evlenmeyi hükiưmsüz addetmiştir. Neuchatêl Üniversitesi Hukuk Fakxültesi Profesörlerinden Charles Knapp, pek haklı olarak, federal mahkemenin bu içtihadını teirkit etmektedir. «Charles Knapp, le mariage fictif et la nationalité de la femme marieé, leçon publique donnée le 8 mai 1940 à l'Universitél de Neuchatél p 4, et ss.».

(12) Yabancr bit kadının dinî nikâhı kabul eden bir memlekette bir Türkie dinî șekilde evlenmesi Devletler Hususî̀ Hukułkunun esasłı kaidelerinden biri olan Locus Regit Actum prensibi geregince gayrı mevcut bir evlenme addolunamaz. 
D - Sabık ecnebi kadının aslî tabiiyetine rücuu — vatandaşlık kanununun 13 üncü maddesinin ikinci fıkrasında cevlenme ile tabiiyeti değişmiş olan sabık ecnebi kadınlar, Türk kocalarından her hangi bir sebeple evlilik halinin zevaliyle ayrldıkları tarihten itibaren ü̧ sene zarfında tabiiyeti asliyelerine. rücu hakkın haizdirler»" denilmektedir.

$\mathrm{Bu}$ flkradan da anlaşldı̆̆ı gibi, Türk vatandaşiyle evlenerek kocasına izafeten Türk vatandaşĭğmı iktisabetmiş olan kadınların Türk kocalariyle evlenme muamelelerinin kanunî hükümlerimize tevfikan fesih veya iptali veya boşanma veyahut da kocalarının ölümü gibi haller dolayısiyle evlilik halinin zevaliyle ayrılan kadınlar otomatik olarak aslî tabiiyetlerini almamakta, kanun bunlara tabiiyeti asliyelerine rücu için üç sene içinde kullanıIması gereken bir hiyar hakkı "droit d'option" tanimaktadır.

Kadın, kanunun kendisine bạşettiği bu opsiyon hakkını zamanında kullanmadığı takdirde Türk tabiiyetini muhafazada devam eder. Binaenaleyh, aslî tabiiyetine geçebilmesi için vatandaşlık kanununun 7 nci maddesi hükmünden istifade etmek cihetine gidebilir. Bu maddeye göre, Türk vatandaşlığından çıkmak müsaadei mahsusa istihsaline mütevakkıftır. İşbu müsaade vatandaşhıtan çıacak olan kimsenin Dahiliye Vekâletine müracaatı ve Icra Vekilleri Heyeti karariyle istihsal olunabilir.n

Şuna işaret edelim ki, 13 üncü madde ile bahşedilen hryar hakkını kullanmak kat'î netice doğurur, izin bahis konusu değildir. Başka bir deyimle hükûmetin takdir hakkı yoktur. Halbuki müsaade ile vatandaşlıktan çıkmak meselesi hükûmetin takdirine terkedilmiştir. Hükûmet müsaadeyi verip vermemek hususunda muhtardır. Memleketin menfaatini göz önünde bulundurarak müracaati reddedebilir.

13 üncü maddenin evlenme ile Türk vatandaşlı̆̆ alan sabık ecnebi kadınlara tanıdığı bu hyyar hakkının aslî tabiiyet lehine kullanılması zaruridir. Eğer kadın bu hakkı başka bir tabiiyet almak için kullanacak olursa bu hükịm ifade etmez. Almak istediği bu tabiiyeti ancak müsaade ile iktisabedebilir.

Burada evliliğin zevalini mucip olan sebepleri ayrı, ayrı incelemek yerinde olur.

1 - Ölüm - Kocanın ölümü ile evlilik rabıtası ortadan kalktığı takdirde karı ölüm tarihinden itibaren üç sene içinde 13 üncü maddenin tanıdığı option hakkın kullanarak aslì tabiiyetine rücu edebilir. 
2 - Boşanma - Karı kocadan birinin diğeri aleyhine açacağ boşanma davasının müsbet şekilde neticelenmesi evliliğin infisahını mucip olacağından karı yine bu hakkı kullanarak aslî tabilyetine rücu edebilecektir. Ancak burada üç senelik müddetin başlangıcı boşanma hükmünün verildiği tarih olmayı temyiz süresinin geçmesi veya hükmün Yargitay tarafından onanması suretiyle kesbi kat'iyet ettiği tarihtir.

3-Gaiplik - Kocanm, Medenî Kanunumuzun (31) inci maddesi mucibince kaybolmasi gaiplik kararınm verilmesini istilzam eder. Ancak mücerret gaiplik kararının mevcudiyeti karıya hiyar hakkını kullanmak salâhiyetini vermez. Çünkü, hukukumuzda gaiplik kararının verilmiş olmasiyle evlilik infisah etmiş değildir. Evlenmenin münfesih olabilmesi için mahkemenin, feshe karar vermesi lâzımdır. Gaiplik kararı dolayısiyle evliliğin feshi Medenî kanunun 94 üncü maddesinin ikinci flkrası gereğince, gaiplik karariyle birlikte talep edilebileceği gibi ayrıca da dava $t$ dilebilir. Binaenaleyh, fesih halinde, fesih hükmünün kesbi kat'iyet ettiği tarihten itibaren kadm muayyen müddet içinde hakkı hyyarını kullanabilecektir.

4 - Batil evlenmeler - Butlanina karar verilen evlenmeler dolayısiyle kadının opsiyon hakkını kullanması hususunda iki halin birbirinden tefriki icap etmektedir:

a - Kadının hüsnü niyetli olması - Batıl olan bir evlenmede kadın evlenme hakkındaki iradesini jzhar ederken butlan sebebine vâkıf değildiyse hüsnü niyetli sayılacak ve Medenî kanunun 126 nict maddesine göre evlenme ile iktisabettiği vaziyeti muhafaza edeceğinden butlan kararının mevcudiyetine rağmen evlenme ile kazandığı Türk vatandaşlığını muhafazada devam eyleyecektir. Bu itibarla haiz olduğu tabiiyeti kaybedebilmesi için üç seine zarfunda tabiiyeti asliyesine rücu eylemesi lâzımdır. Ựç senelik müddetin başlangicl hükmün kat'iyet kesbettiği tarihtir. (13).

(13) Hukuk Usulü Muhakemeleti Kanununun 18 inci maddesinde "Türkiyede ikametkâhı bulunmıyan Türk tebaası Türkiyede sakin değilse ahkâmı şahsiye noktasından Türkiyedeki son ikametgâhı mahkemesinl, buiunmadiğı halde Ankara mahkemesine aittir. denilmekte olmasına nazaran Türk Medenî kanunu hükümleri tatbik edilmek suretiyle dahi olsa, evliliğin feshine, butlanına ve boşanmiya dair verilen ve kesbi kat'iyet eden yábañcı memleket mahkeme kararlari kadıná hakkı hyarinı kullanma salâhìetini vermez. Zira, Türk hukuku bakımından evlilik birtigi devam etmektedir. 
b - Kadının sui niyețli olması - Butlanina hükmedilen bir evlenmede kadın butlan sebebine vâkuf idiyse sui niyetli addedilir ve bu takdirde kadının aslî tabiiyetine rücuu meselesi önem kazanır.

Medenî kanunumuzun 126 mel maddesinin mefhumu muhalifinden anlaşlacağ 1 üzere sui niyetle evlenen kadin evlenme ile iktisap ettiği vaziyeti muhafaza edemiyeceğinden bu maddeye göre kadının aslî tabiiyetine rücu edebilmesi için hıyar hakkmı kullanması imkânsız olur. Çünkü, esasen butlan karariyle evlenme ile iktisap ettiği vaziyeti kaybeder ve binnetice Türk tabiiyetini de muhafaza edemez.

Vatandaşlık kanununun 13 üncü maddesi «evlenme ile tabiiyeti değişmiş olan sabık ecnebî kadınlar Türk kocalarından herhangi bir sebeple evlilik halinin zevaliyle ayrlddkları tarihten itibaren üç sene zarfında tabiiyeti asliyelerine rücu hakkını haizdirler" şeklinde bir hüküm koymasma nazaran acaba bu madde. Medenî kanunun 126 inci maddesini tâdil etmiş midir; başka bir deyimle, kadın sui niyetli olsa dahi Türk tabiiyetini kaybedebilmesi için hakkı hıarıni kullanmak zorunda midir?

Bu mesele ihtilâflıdır. Profesör Ahmet Sámim Gönensay «Bu muahhar kanun bir Türkle evlenen ecnebî kadının evliliğin butlan sebeplerinden herhangi birisiyle feshedilmesi halinde sui niyet sahibi bile olsa evlenme ile iktisap ettiği tabiiyeti muhafaza etmesini kabul ederek Medenî kanunun evlenme ile iktisap edilen yeni tabiiyetin muhafazası için kadinm hüsnü niyete müteallik hïkmünü tâdil eylemiş" demektir. (14).

Profesör Ahmet Esat Arsebük de aynt fikirdedir. (15).

Mustafa Reşit Belgesay ise «kadın sui niyetle, yani butlan sebèbine vâhıf olarak evlenmiş ise butlan karariyle Türk vatandaşlı̆̆nı kaybeder demekte (16) Hikmet Gündüz, (17) Kemaleddin Birsan, (18) Reşad Aksoy, (19) Suphi Nuri İleri, (20), Schwarz (21) bu noktai nazara taraftar görünmektedirler.

(14) Samim Gönenşay, Medenî hukuk. cild II, Sh. 70.

(15) Ahmet Esat Arsebük, Medenî hukuk, Cilt II. 656.

(16) Mustafa Reşit; Türk vatandaşlığı kanunu şerhi. Sh. 37.

(17)Hikmet Gündüz, Evlenmenin tâbiiyet ïzerinde tesiri ve vatandaşıık kanunumuzun bu husustaki hükümleri. (Adliyl ceridesi, 1941, sayı 4 Sh. 263.)

(18) Kemaleddin Birsen, Devletler hususî hukuku, Cilt: 1, Sh. 36.

(19) Reşat Aksoy, Adi geçen eser, 54.

(20) Suphi Uuri İleri, Yasaların Çatışmass, Sh. 42.

(21) Schwarz, Aile Hukuku, Cilt: 1, Sh, 136. 
Profesör Muammer Raşit Seviğ vatandaşlık kanununun, Medenî kanunun 126 nncı maddesini tâdil ettiği hakkındaki fikri doğru bulmakla beraber mezkûr maddeyi tâdilden kurtarmak maksadiyle şöyle bir tefsir tarzı ileri sürmektedir: “Evlenmenin tabiiyet üzerinde müessir olması için sahih olması şarttır. Sahih olmadığı hâkimin karariyle tebeyyün edince kadının tabiiyeti üzerindeki tesiri noktasından kadının hüsnü niyetle evlenmiş olup olmamasına göre hüküm verilmek lâzımgelir. Kadın hüsnü niyetle evlenmiş ise 126 nncı madde mucebince evlenme ile iktisabettiği vaziyeti muhafaza eder. Muhafaza ettiği için de vatandaşlık kanununun 13 üneü maddesinin son fıkrasına tevfikan üç sene zarfında aslî tabiiyetine rücu hakkını haiz olur. Fakat kadın hüsnü niyetle evlenmiş değilse 126 ıncı maddenin hükmüne nazaran evlenme ile iktisap ettiği vaziyeti muhafaza etmediği ve bu da tabiiyet bakımından tâ evlenme zamanına râci olduğu cihetle kadın hiç tabiiyet değiștirmemiş gibi olur. $\mathrm{Bu}$ takdirde ise kadına rücu hakkkını tanımağa mahal yoktur. Rücu mihanikî bir surette vâki olmuştur. Şu halde vatandaşlık kanunu henüz aslî tabiiyetine rücu etmemiş kadınları istihdăf etmiş ve bunlar hakkında herhangi bir sebeple evlilik hali zeviłi tarihinden itibaren ị̈ç sene zarfında aslî tabiiyetlerine rücu hakkmı bahşetmiştir. Bu yolda bir tefsir Medenî kanunun $126 \mathrm{incl}$ maddesini tadilden kurtararak olduğu gibi muhafaza eder. (22).

Fikrimizce Sayın Profesör'ün bu tefsir tarzı 126 mcl maddeyi tâdilden kurtarırsa da, Medenî kanunun 124 üncü maddesinin koyduğu esaslı bir prensibi ihlâl etmiş olur.

Noktai nazarımıza göre, kadın sui niyetli olsa dahi butlan karariyle, iktisabetmiş olduğu Türk vatandaşlığın kaybetmez. Aslì tabiiyetine rücu edebilmesi için hıyar hakkını kullanmalıdır. Bu hal surếi vatandaşlık kanununun 13 üncü maddesi sarahatına ve ruhuna uygun düser.

E -- Opsiyon hakkını kullanan kadınların durumu -- Türklerle evlenmek suretiyle Türk vatandaşlı̆̆mı iktisap ve opsiyon haklarını kullanarak aslî tabilyetlerine rücu eden sabık ecnebi kadınlara kanun bir takım ödevler yüklemektedir. Filhakika, 13 üncü maddenin son cümlesinde "şu kadar ki, ecnebiliğe avdet etmek isteyen kadının Türk babadan çocuğu mevcut değilse ikametgâhını yabancı memlekete nakletmesi şarttır» denilmektedir. Bu hükme göre hıyar hakkını kullanarak tabiiyeti asliyesine rücu eden kadının ikametgâhmı

(22) Muammer Reşit Sevǐg, adi geçen eser, Sh. 77. 
Türkiyeden yabancı memlekete nakledip etmiyeceği Türk kocasından çocuğu olup olmamasına bağhıdır. Eğer Türk kocasından çocugu varsa kadın için ikametgâhımı ecnebi memlekete nakil mecburiyeti yoktur, aksi takdirde, ikametgâhını mutlak surette nakletmek zorundadur.

Burada önemli gördüğümüz bir noktaya dokunmadan geçemiyeceğiz: Vatandaşlık kanunumuz Türk babadan çocuğu olmıan sabık ecnebi kadının ikametgâhını ecnebi memlekete nakledeceğini tasrih etmekte ise de, tekrar Türkiyeye gelip gelemiyeceği, ikametgâhını ne vakte kadar nakledeceği ve mallarının tasfiyesi hakkında hiç bir sarahati ihtiva eylememektedir.

Kanun ikametgâhın yabancı memlekete naklini mecburî kılmasına ve ikametgâh da yerleşmek niyetiyle oturulan yer olmasına nazaran aslî tabiiyetine rücu eden ve ikametgâhmi yabancı memlekete nakleyleyen kadının muvakkat bir zaman için Türkiyeye gelmesine mâni yoktur. Zira, bu kadınlar için Türk tabiiyetinden çıkanlar hakkındaki Türkiyeye girme için mevzu takyitler bahis konusu olamaz. (23).

İkametgâhın nakli müdđetinin tâyini huisusu hükûmetin takdirine bağli bir meseledir. (24).

Vatandaşlık kanunundà opsiyon hakkını kullanan ve Türk babadan çocuğu olmıyan sabık ecnebi kadınların mallarınin tasfiyesine dair bir emir mevcut olmamasma nazaran burada 8 inci maddenin kıyasen tatbiki fikrimizce doğru değildir. (25).

F - Türkle evlenen kadınların evvelki kocalarından olan çocuklarinin tabiiyeti -

Vatandaşlık kanununun 13 üncü maddesinin 3 ve 4 üncü cümlelerinde: "Ecnebi kadının bir Türkle evlenmesi ecnebi kocasından evvelce olan çocuklarının tabiiyetine tesir etmez. Ancak babaları sağ değilse çocuklarin tabiiyeti analarma tâbi olưn denilmektedir. (26).

(23) Abdülhak Kemai Yörük, Devletler hususî hukuku, kitap I. s. 175.

(24) Muammer Reşit Sevił, adı geçen eser, cilt: I. s.. 78. Mustafa Reşit Bilgesay'a göre burada kanunun 8 inci maddesinin kryasen tatbikı lâzıngelir ad1 geçen eser, s. 37 .

(25) Kemaleddin Birsen; malların, kanunun 8 inci maddesinin kryasen tatbikı suretiyle tasfiyesi icabettił̌ fikrindedir. Ad geçen eser, s. 36 .

(26) Kanun vazıı tefsir yoliyle Türk vatandaşlığının iktisabında da çocukların babalarına veya dul analarına tebean Türk olacaklarını kabul eylemektedir. (M. 5). 
Kanunumuzun bu hükmüne göre Türkle evlenen ecnebi kadının evvelki kocasından çocukları varsa, bunlarm analarma tebaan Türk tabiiyetini iktisap edebilmeleri için babalarının sağ olmaması lâzımdir. Binaenaleyh, burada gözönünde bulundurulacak cihet evlenme esnasında çocukların babalarının sağ olup olmadığıdır. Söylemeğe hacet yoktur ki, babalari sağ olmasa dahi Türk tabiiyetine geçecek. olan çocuklar reşid olmıyan çocuklardır. Evlenme reşid olanların tabiiyeti üzerine hiç bir tesir icra etmez.

Vatandaşlık kanunu Türk vatandaşlariyle evlenen ecnebi kadmlarına olan bağlllıklarının herhangi bir şekilde tahakkuk edip etbir hüküm ihtiva etmemektedir. Zikri geçen kadinların, Türklerle evlenmelerinden evvel, evlilik ḋışında doğan çocukları mevcut olduğu takdirde dikkat edilmesi gereken nokta bu çocukların babalarına olan bağlilıklarının herhangi bir şekilde tahakkuk edip etmediğidir.

Eğer bunların babalariyle olan irtibatları tahakkuk etmiş ise, 13 üncü madde gereğince babalarının sağ olup slmadığına bakılacak, babaları sağ ise analarına tebaan Türk tabịyetini alamıyacaklardir.

Eiğer irtibatları tahakkuk etmemiş ise, bunlar 13 üncü maddenin șümulü dairesine giremiyeceklerinden analariyle beraber Türk vatandaşlığı sıfatını alacaklardır.

G - Opsiyon hakkını kullanan kadınların çocukları -- Türklerle evlenmek suretiyle Türk tabiiyetini alan yabancı kadinların çocuklarının analarına tebaan iktisap ettikleri Türk vatandaşlığınx analarmm aslî tabiiyetlerine rücuu dolayısiyle kaybedip etmiyecekleri meselesi önemlidir.

Bu çocuklar analarına tebaan Türk vatandaşı olduklarına göre bu kaidenin Türk vatandaşlı̆̆gndan çıkarken dahi carî olması tabiî olur. Başka bir deyimle Türk vatandaşlığına girerken olduğu gibi Türk vatandaş̧ığından çıkarken de küçưkklerin tabiiyeti analrına tâbi olmak lâzımgelir. (27).

\section{EVLENMENIN TABİIYETE TESIRINININ HÜKÜMLERI}

Evlenmenin tabiiyete tesixinin hükümleri şunlardir:

1 - Makabline şamil değildir: Evlenme ile Türk vatandașlığını iktisap eden kadın, evlenme akdinin yapıldığı tarihien itibaren Türk

(27) Muammer Reşit Seviğ, adt geçen eser, Cilt: I. s. 96. 
sayılır; akdin in'ikadindan evvelki muamelelere Türk vatandaşlığ sufatmion hiç bir tesiri yoktur.

2 - Daimidir: Kocasının Türk tabiiyetinden çıkması veya ıskat edilmesi kadının evlenmekle iktisap ettiği Türk vatandașlığına tesir icra etmez; kadın Türk olarak kalır. Tabiiyetini kaybedebilmesi için müsaade ile Türk vatandaşlığından çıkması, veya evliliğin sona ermesi dolayrsiyle opsiyon hakkını kullanarak tabijyeti asliyesine rücu etmesi yahut da Türk vatandaşlığından 1skat edilmesi zaruridir.

3. Mutlaktir: Evlenmekle Türk tabiiyetini iktisabeden sabik ecnebi kadınların hukukî durumu an asıl Türk olanların hukukî durumundan farksızdır. Binaenaleyh, hukuktan istifade bakımindan yabancılar için konan takyidler bunlar hakkında bahis konusu olamaz. Yalnız, vazu kanun tabiiyetten iskatta an asıl Türk olanlarla sonradan Türk tabiiyetini iktisabetmiş bulunan sabılk ecnebiler arasunda bir fark kabul etmistir:

Filhakika, vatandaşlik kanununun 11 inci maddesi mucebince Türkiye Cumhuriyetinin dahilî ve haricî emniyetine mugayir ef'al ve harekâta tesaddî etmek veya askerlik hakkındaki kanunların emrettiği mükellefiyetleri ifa etmemek aslen Türk olanlar için 1skatı mucip olmadığı halde sonradan Türk vatandaşlığını iktisap edenlerin tabiiyetten ıskat edilmesini intaç edebilir.

4 - Şahsîdir: Prensi pitibariyle, yabancı bir kadının Türkle evlenmesi evvelki kocașindan olan çocuklarmun tabiiyetine tesir etmez, yani şahsîdir. Prensip itibariyle diyoruz çünkü, bir halde evlenme yalnız evlenen kadınun tabiiyetine tesir etmekle kalmayı, aynı zamanda çocuklarınin da Türk olması neticesini doğrur. Bunun için tek şart bu çocukların babalarının sağ olmamasıdır.

Doç. Dr. Osman Fazll Berki 